\title{
ENGLISH PHONICS LEARNING USING ONLINE GAME AMONG MALAYSIAN PRIMARY SCHOOL STUDENTS: THE UPSHOTS AND THEIR PERCEPTIONS
}

\author{
Nur Afiqah Amalina Baharudin ${ }^{1}$ \\ Faculty of Education, \\ Universiti Kebangsaan Malaysia (UKM), Malaysia \\ (Email: afiqahamalina90@gmail.com) \\ Melor Md Yunus ${ }^{2}$ \\ Faculty of Education, \\ Universiti Kebangsaan Malaysia (UKM), Malaysia \\ (Email: melor@ukm.edu.my)
}

Accepted date: $16-03-2019$

Published date: 11-07-2019

To cite this document: Baharudin, N. A. A., \& Yunus, M. M. (2019). English Phonics Learning Using Online Game Among Malaysian Primary School Students: The Upshots and Their Perceptions. International Journal of Humanities, Philosophy and Language, 2(6), 6377.

DOI: $10.35631 /$ ijhpl.26006

\begin{abstract}
Due to the lack of phonemic awareness in English, it is hard for students to read in this language appropriately. As reading competence is very important to be highlighted, this issue need to be scrutinized in order to ensure that students could acquire the phonics learning thus, developing their reading skill. So, this study attempts to investigate the implementation of online game in learning English phonics and their perceptions about the lesson among Year 1 students in SK Kopok, Pasir Gudang, Johor. To acquire this, a set of questionnaires was distributed to all participants involved and all of them have been interviewed in order to gather the data in depth. Pre and post tests were utilized to determine if there any significant difference occurs throughout this study. These instruments were administered among the Year 1 students in this school and there were 15 participants involved in the study. The analysis of the data reveals that most of the students have improved their English phonics lessons by using online game. It is highly significant to determine the reasons that contribute to the findings as this would help various stakeholders to enhance the reading ability among the students. The theory of Jean Piaget regarding the assimilation and accommodation will be drawn deeply in this study as it provides the understanding of how learning takes place when playing the online game. This paper will also discuss the recommendations to improve the phonics lesson as to attract the students' attention as well as to motivate them to read in English. Thus, the results in the findings will be further discussed throughout this paper.
\end{abstract}

Keywords: Phonics Learning, Online Game, ICT, Reading Competence, ESL Primary Learners 


\section{Introduction}

Globally, English language has been used widely for decades ago as a mean of communication until at the present time. The importance of acquiring and using English as a medium of communication has been notified by some of the scholars on those days. This can be seen in the article written by Crystal (2013), as he claimed that,

"As early as 1780, John Adams, one of the founding fathers of the United States of America and its second president, commented that 'English is destined to be in the next and succeeding centuries more generally the language of the world than Latin was in the last or French is in the present".

In this era, the practice of English language is much more essential and demanding by all people across the globe. This can be proved by Marsh (2006) as cited in Ryhan (2014) who asserted that, "a large number of international education institutions expressed a significant interest in adopting English medium of instruction". This proves that the importance of English is not just important during those days, but it is still being highlighted until at the present time.

In Malaysia, the official language is Bahasa Malaysia and English is acknowledged as the second language. The use of English is very demanding at this era as it becomes one of the requirements to be accepted in the workforce. This is supported by the Prime Minister of Malaysia, Tun Mahathir Mohamad where he clarified that, "the country's ability to survive and thrive would be in jeopardy if the future generations of Malaysia are not well-versed in English, the language of commerce and trade", as Joash (2015) cited in (Yunus \& Saiful Islam, 2017). Besides, students are required to at least pass the English subject as it is one of the core subjects taught in school. This shows that English has been practiced decades ago by people all over Malaysia and the demand for them to acquire this language still persists until today.

Learning a language is not easy especially when we are learning second language. People might face some difficulties in learning a language especially kids. It may be because they need more time to attain the language compared to the adult learners. In school, learning English language is quite challenging to most of the primary students particularly for those who come from a low socio-economic background where they are not exposed to English language at home. They only learn the language when they are at school. Thus, their proficiency level of English is much lower compared to those who have been practicing the language with their parents at home. This results the number of students who can read English appropriately is very low.

In a study conducted by McArthur et al (2012), they ascertained that, "around 5\% of English speakers have a significant problem with learning to read words". These authors believed that, "poor word readers are often trained to use letter-sound rules (phonics) to improve their reading skills", (McArthur et al, 2012). At the end of the research, they found that, "phonics training appears to be effective for improving some reading skills", McArthur et al (2012). This concludes that by applying phonics in learning English could help the learners to develop their reading skills to be better. In the article written by Berkling and Pflaumer (2014, p. 33), according to The National Reading Panel (NRP) in 2000, "phonics is one viable method for teaching spelling in a very systematic manner that supports all students". Teaching phonics is not only important for the students to improve their pronunciation and reading skills but also to enhance their knowledge in spelling. Throughout this study, it is 
hoped that the online game will offer positive impacts to the students in learning English. Therefore, the purpose of the study is to examine the use of online game in learning English phonics among the primary school students and their perspectives on using it in classroom.

The acquisition of English phonics is very important to be centralized among the students since they are in the early childhood learning. According to Birch (2014), she emphasized that, "phonological knowledge is crucial for fluent alphabetic reading with comprehension". In other words, teachers should stress on the importance of learning phonics among the students so that their reading skills can be developed thus improve their proficiency in English language. It is crystal clear that the importance of using online game in learning English phonics has been highlighted as this could improve not only the students' development in reading skill but also assist the teachers' level of knowledge and skills in ICT. By discovering several teaching techniques might help the school and teachers to prepare more attractive learning activities during the English class. In this case, teachers should recognize the students' ability and learning preferences so that, various activities can be carried out in the same lesson. This is to cater all the students' needs in learning. For students who need particular attention from teachers, special materials should be provided. This can be related with Shift 1 in the Blueprint where the government will increase the investment in physical and teaching resources for students with specific needs, (Malaysia Education Blueprint, 2012). Therefore, the authority would provide more technology tools to be utilized in teaching and learning process. As a result, it could not only attract the students' attention but also improving their understanding in learning the target language.

In this study, there were several factors that contribute to the successfulness of implementing online game in teaching phonics to the primary school students as can be seen in Diagram 1. By using images and colours throughout the game could attract the students' attention and interest to learn thus, it will help them to keep engaged till the end of the lesson. Besides that, by using appropriate images or characters in the game could motivate the students to learn more. The other factor that could affect the successfulness of implementing online game in teaching phonics to the primary school students which is the utilization of ICT would create a center of attention among the students and encourage them in the learning. Last but not least, teachers play a very important role as they need to ensure that the text used in the game must be suitable with the students' level so that the learning process can be delivered well. 


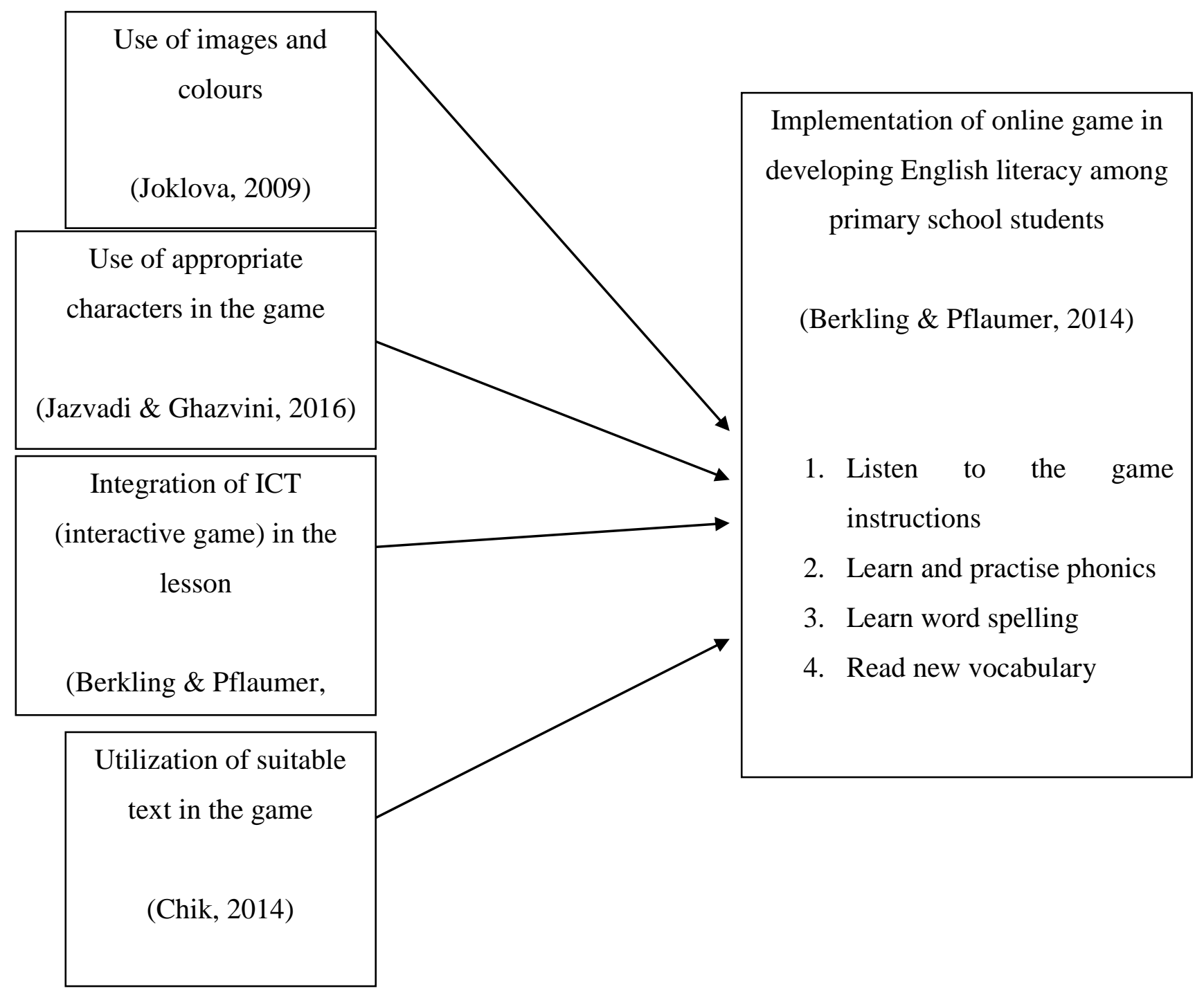

Diagram 1

In school, the number of students who cannot read in English appropriately is high because they are not able to recognize the letters as well as the sounds of letters (phonemes). They could not relate the connection between the letters and their sounds which will lead them to reading phase. This is because they do not have the knowledge of phonics and reading acquisition. Therefore, this study will further discuss on how students would learn English phonics better using online game.

\section{Research Objectives}

In this study, there were two research objectives that need to be attained which are :

1. To examine the implementation of online game in learning English phonics among the primary school ESL learners.

2. To identify the students' perspectives in learning English phonics by using online game during the lesson. 


\section{Research Questions}

In order to achieve the research objectives, there were two research questions that had be looked into throughout this study which are:

1. Is there any significant difference in implementing online game and the achievement in learning English phonics among primary school ESL learners?

2. What are the students' perspectives in learning English phonics by using the online game during the lesson?

\section{Literature Review}

Teaching and learning processes should be more effective and interactive especially in this digital era. This is because learners nowadays as well as teachers are prone to the utilization of ICT tools in their daily life including in learning purposes. According to Chik (2014), "interest in learning through digital game has intensified in recent years, and researches and teachers have been keen to harness the pedagogical benefits in classroom contexts". Besides, "they (game) create a fun environment in which learners and even the teacher become more interested in learning and teaching process", Ashraf et al (2014). Therefore, the implementation of ICT tools in teaching and learning could cater the learners' preferences in learning other than fulfilling one of the government's aspiration in education which is to instill and practice the $21^{\text {st }}$ Century Learning among the students in classrooms.

$\mathrm{Fu}$ (2013) asserted that, "Information and Communication Technology (ICT) includes computers, the internet, and electronic delivery systems such as radios, televisions, and projectors among others, and is widely used in today's education field". It proves that the utilization of ICT in teaching and learning is not something new and has been applied by many educators all over the world. The integration of ICT tools in learning a language can be incredibly beneficial to the students. This is because by incorporating interesting game through ICT tools could attract the students' attention to learn. It will help the students to focus more on learning as it is more attractive compared to go through the lesson in conventional way; the 'chalk and talk' way of teaching. This is highly supported by Uberman (1998) as cited in Bakar and Nosratirad (2013) who claimed that, "the use of a computer as a learning tool has influenced many adults and, since the past century, it has become an important factor in learning language". Since then, learning using ICT has been widely practiced all over the world.

In a research carried out by Falloon (2013), he claimed that, "the past few years have seen an array of new technological gadgets arrive on the education scene". This notion proves that the number of schools implementing technologies in teaching and learning processes is elevating occasionally. The implementation of computers as teaching and learning tools have also attract the students to learn more during the lesson. This is supported by Chang and Lehman (2002) as cited in (Chang \& Lin, 2013), they asserted that, "research in computer-assisted language learning (CALL) has revealed that students were motivated and liked working with the computer-based courseware". According to Bakar and Nosratirad (2013), "in this century, research on the potential of digital educational game in enhancing language learning has increased very fast from year to year". Other than that, Sayed Yusoff et al (2014) declared that, "digital game which are commonly regarded as a form of entertainment, has been proposed as an effective tool for engaging students in learning activities".

There is a significant relationship between phonological learning with reading acquisition. It is highly essential for the students to have a very good knowledge and skills in phonics in 
order to enhance their reading acquisition to be better. According to Yunus et al (2016), "reading comprehension can be enhanced when computer-mediated passages are employed to develop or to control options for obtaining information". Thus, by using computer as the technology tool in teaching will help the students to improve their phonics ability as well as in their reading competence. Other than that, online game could also provide clearer contents in more interactive ways. In the study conducted in German by Berkling and Pflaumer (2014), they affirmed that, "as the game is interactive, the sound of the grapheme within the given context becomes clear". By using pictures or characters in the online game could attract the students' attention and motivation to learn more during the lesson. This is because they are prone to look at the pictures or text accompanied by pictures more compared to the texts utilized. This is highly supported by Yang et al (2013) as they discovered that, "students spent more time reading texts and attended more to the text-picture slides", (Yang et al, 2013). This illustrates that students would get attracted more to the pictures or images rather than to read sentences or texts.

Online game has been selected to be the platform of learning English phonics as this could offer the students not only a way of learning but also to cater their interest of playing game. This is highly supported by Godwin-Jones (2014) who asserted that, "there has been a substantial increase in recent years in the interest in using digital games for language learning". In this study, the online game implemented was 'Teach Your Monster to Read'. It was chosen because it provides the target item (phonics) and the language needed which is English language and it is a free online game. So, it is much easier for the teachers and students to access to the game at no cost. When playing the game, the students have to listen and say out the sound of the phonics while doing the activity. In addition, the characters in the game which are monsters are very familiar to the students as the characters used are almost the same as in the English Textbook (Supermind) that they learn in clasroom. Students are exposed with the same phonics and vocabulary repeatedly for few levels before changing them into the new one. This will enhance their learning of the target language. Mohammad Ali Heidari-Shahreza et al. (2014) suggested that, "English teachers put incidental vocabulary acquisition within the perspective of longitudinal, intensive and systematic vocabulary recycling where the learners' knowledge of vocabulary is reinforced and accumulated over time".

\section{Methodology}

Throughout this study, a mixed-method research design was employed. According to Morse and Niehaus (2016), they defined the term 'mixed-method' as, "the incorporation of one or more methodological strategies, or techniques drawn from a second method, into a single research study, in order to access some part of the phenomena of interest that cannot be accessed by the use of the first method alone". In this study, pre-test and post-test were used in order to recognize if there any significant difference of the implementation of online game to learn English phonics among the participants. The result from the Screening 1 was regarded as pre-test while the result for post-test was taken from Screening 2. Both of these tests were taken from the LINUS screenings results. By having these pre and post-tests helped the researcher to determine whether the students are improving their phonics learning in English or not. In the results, the data was calculated and presented using simple percentages based on Pass or Fail results as LINUS has no total marks to be calculated.

There is plethora of studies that utilizing questionnaire as the instrument in collecting data. According to Phillips (2013), "questionnaires are widely used because they are cost effective and can be administered to large groups of people". In this study, a questionnaire has been 
adapted from a study conducted by the Centre for the Study of Learning and Performance (CSLP) at Concordia University in Montreal, Quebec in collaboration with the Eastern Townships School Board and the Sir Wilfred Laurier School Board. The items were adapted to suit with the participants' level of understanding and the online game utilized in this study. All items in the questionnaire were translated into Malay Language by the researcher as the participants could not understand English very well. They just have to tick (/) to 'Yes' or 'No' box to respond to the questionnaire. Moreover, a short interview was carried out among the participants in order to obtain their perceptions on what do they like and do not like about learning English phonics using online game. According to Singh (2015), "interviewing is a rigorous data collection technique; it can span many days or months and yield several volumes of data". The interview questions have been adapted from a study carried out by Yang and Quadir (2018) who investigated the students' experience and feedback in learning using online game. During the interview, the researcher also translated the questions into Malay Language as the participants could not understand English well. In addition, the researcher provided some examples of ideas if the participants did not respond any to the question uttered. This research involved 15 students from Year 1 as the participants. These selected students are in the same school which located in the sub-urban area of Pasir Gudang, Johor, the southern part of Malaysia. All of the students involved were those who did not pass the reading screening specifically in phonics constructs (Construct 2 and 3). Therefore, all of the participants are at the same level of proficiency in the target language.

All the samplings (students) were chosen based on purposive sampling technique. This was done by choosing the students who did not pass the first LINUS reading screening thus, they have the same level of ability in reading English. As for the instrument (questionnaire), it was distributed to all participants in the classroom at the same time guided by their teacher (the researcher). They were responding to the questionnaire during English period while the other students who were not the participants of the research were given another task to be completed. It took a person to complete the survey within 15 minutes. After the participants have responded the questionnaire, the evaluation of the data was calculated using simple figures and percentages.

Before proceeding to the actual study, a pilot-test was conducted among 30 good Year 1 students in a school and they had to respond to the items set in the questionnaire. This is to ensure the validity and reliability of the questionnaire prepared, a pilot-test was administered as Phillips (2013) declared that, "the aim of the pilot-test is to detect any mistakes in the questioning and to correct them before the main survey". Other than that, he also added that, "based on the pilot-test, the researcher will be able to make changes that will help maximise response rate and minimise confusion among respondents", (Phillips, 2013). The result of the pilot test showed that they could learn and improve their understanding in learning English phonics better when using online game.

\section{Results}

Research Question One: Is there any significant difference of implementing online game in learning English phonics among primary school ESL learners?

\section{Pre- Test and Post-Test}

Based on the pre and post-tests, the results indicated a highly significant improvement among the participants. The outcomes of both pre and post tests were calculated and shown clearly in the table below. The results are shown based on different constructs; Construct 2 (sound out the phonemes) and Construct 3 (blend the phonemes). 


\section{Construct 2: (Sound Out Phoneme)}

\begin{tabular}{|c|c|c|}
\hline & $\begin{array}{l}\text { Pre-Test } \\
\text { (Screening 1) }\end{array}$ & $\begin{array}{l}\text { Post-Test } \\
\text { (Screening 2) }\end{array}$ \\
\hline Respondents & \multicolumn{2}{|c|}{ Passed $(/)$ or Not Passed $(\mathrm{X})$} \\
\hline R1 & $\mathrm{X}$ & / \\
\hline R2 & $\mathrm{X}$ & I \\
\hline R3 & $\mathrm{X}$ & I \\
\hline $\mathrm{R} 4$ & $\mathrm{X}$ & I \\
\hline R5 & $\mathrm{X}$ & $\mathrm{X}$ \\
\hline R6 & $\mathrm{X}$ & / \\
\hline R7 & $X$ & I \\
\hline $\mathrm{R} 8$ & $X$ & I \\
\hline R9 & $\mathrm{X}$ & l \\
\hline R10 & $\mathrm{X}$ & l \\
\hline R11 & $\mathrm{X}$ & I \\
\hline $\mathrm{R} 12$ & $X$ & I \\
\hline $\mathrm{R} 13$ & $\mathrm{X}$ & I \\
\hline R14 & $\mathrm{X}$ & I \\
\hline $\mathrm{R} 15$ & $\mathrm{X}$ & l \\
\hline Total & $\mathbf{0}$ & 14 \\
\hline $\begin{array}{l}\text { Percentage of } \\
\text { pass }(\%)\end{array}$ & $\mathbf{0}$ & 93.3 \\
\hline
\end{tabular}

Table 1

Table 1 shows that there are no students passed Construct 2 (sound out phoneme) in the pretest (Screening 1) but the number of students who passed this construct has been increased to 14 in the post-test (Screening 2). Yet, there is still one student who have not passed this construct in the post-test.

\section{Construct 3: (Blend Phoneme)}

\begin{tabular}{|c|c|c|}
\hline & $\begin{array}{l}\text { Pre-Test } \\
\text { (Screening 1) }\end{array}$ & $\begin{array}{l}\text { Post-Test } \\
\text { (Screening 2) }\end{array}$ \\
\hline Respondents & \multicolumn{2}{|c|}{ Passed (/) or Not Passed (X) } \\
\hline $\mathrm{R} 1$ & $\mathrm{X}$ & I \\
\hline $\mathrm{R} 2$ & $X$ & / \\
\hline R3 & $X$ & / \\
\hline $\mathrm{R} 4$ & $\mathrm{X}$ & $\mathrm{X}$ \\
\hline R5 & $\mathrm{X}$ & $\mathrm{X}$ \\
\hline R6 & $X$ & I \\
\hline R7 & $\mathrm{X}$ & I \\
\hline R8 & $\mathrm{X}$ & l \\
\hline R9 & $X$ & $\mathrm{X}$ \\
\hline $\mathrm{R} 10$ & $\mathrm{X}$ & I \\
\hline R11 & $X$ & l \\
\hline
\end{tabular}




\begin{tabular}{|l|l|l|}
\hline $\mathrm{R} 12$ & $\mathrm{X}$ & $/$ \\
\hline $\mathrm{R} 13$ & $\mathrm{X}$ & $/$ \\
\hline $\mathrm{R} 14$ & $\mathrm{X}$ & $/$ \\
\hline $\mathrm{R} 15$ & $\mathrm{X}$ & $/$ \\
\hline Total & $\mathbf{0}$ & $\mathbf{1 2}$ \\
\hline $\begin{array}{l}\text { Percentage of } \\
\text { pass (\%) }\end{array}$ & $\mathbf{0}$ & $\mathbf{8 0}$ \\
\hline
\end{tabular}

Table 2

Table 2 shows that there is no students passed Construct 3 (blend phoneme) in the pre-test (Screening 1) but the number of students who passed this construct has been increased to 12 in the post-test (Screening 2). However, there are 3 students who have not passed this construct in the post-test.

The achievement of the students in both pre and post-tests is shown in the Graph 1 below.

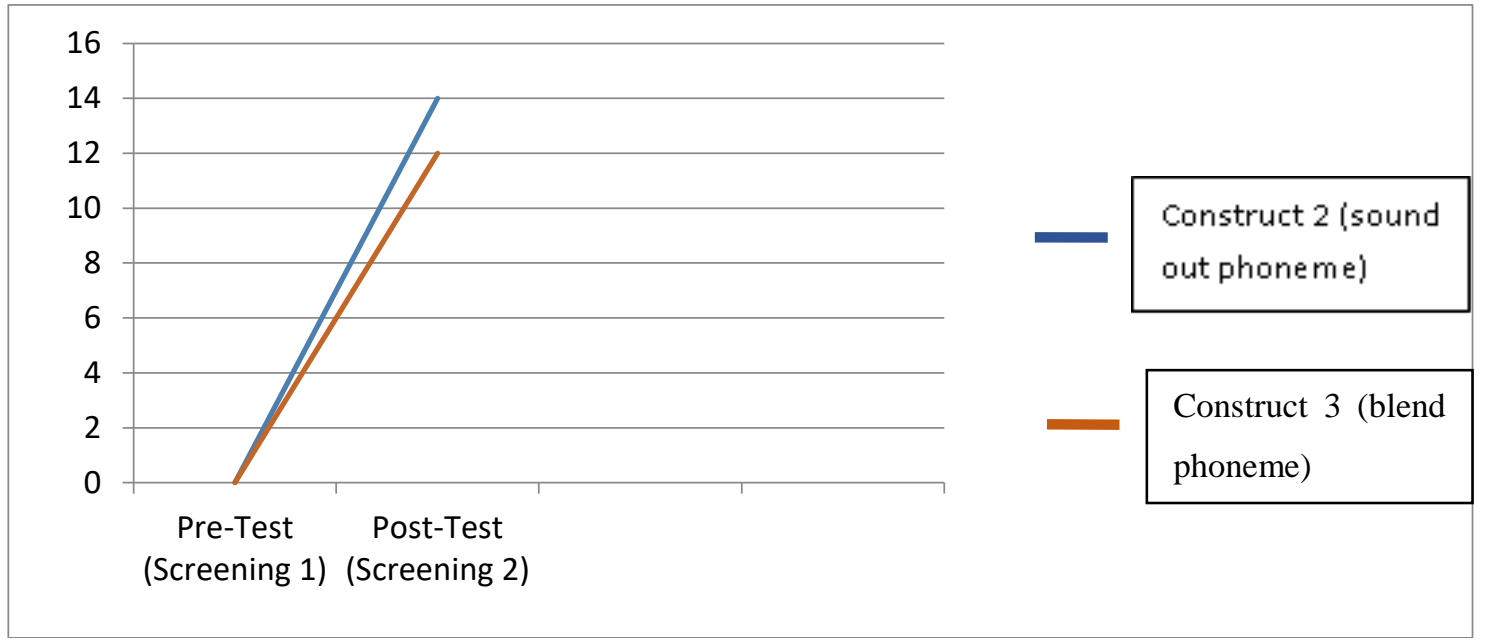

\section{Graph 1}

Based on the result shown in the Graph 1, the number of students passed Pre and Post Tests (LINUS screenings) increases for both Construct 2 (sound out phoneme) and Construct 3 (blend phoneme). In the pre-test (Screening 1), there was none of the students passed in both constructs, but it indicates an increment in the post test (Screening 2) where the number of students who passed the Construct 2 is 14 (93.3\%) and there is 12 students (80\%) passed the Construct 3. This graph explains that the students have developed their understanding in learning English phonics using online game during the lesson.

\section{Questionnaire}

\section{Section 1}

In the questionnaire, Section 1 was about gender ( 4 girls; 27\%) and 11 boys; $73 \%$ ) and the participants' first language which is Malay (100\%). The other questions were also analyzed and tabulated into simple percentages as shown in the Table 3 below. 


\begin{tabular}{|r|l|l|l|}
\hline No. & Questions & $\begin{array}{l}\text { Yes } \\
(\boldsymbol{\%})\end{array}$ & $\begin{array}{l}\text { No } \\
(\boldsymbol{\%})\end{array}$ \\
\hline 1. & Did you go to kindergarten? & 20 & 80 \\
\hline 2. & Do you speak English at home? & 0 & 100 \\
\hline 3. & $\begin{array}{l}\text { Do you have your own smart } \\
\text { phone? }\end{array}$ & 26.7 & 73.3 \\
\hline 4. & $\begin{array}{l}\text { Do your family have smart } \\
\text { phone? }\end{array}$ & 100 & 0 \\
\hline 5. & $\begin{array}{l}\text { Do you use smart phone at } \\
\text { home? }\end{array}$ & 86.7 & 13.3 \\
\hline 6. & $\begin{array}{l}\text { Do you use smart phone for } \\
\text { learning purposes? }\end{array}$ & 13.3 & 86.7 \\
\hline 7. & \begin{tabular}{l} 
Do you love to learn English? \\
\hline 8.
\end{tabular} & $\begin{array}{l}\text { Do you love to play online } \\
\text { game? }\end{array}$ & 100 \\
\hline 9. & $\begin{array}{l}\text { Do you play online game at } \\
\text { home? }\end{array}$ & 86.7 & 0 \\
\hline 10. & $\begin{array}{l}\text { Do you play online game for } \\
\text { learning purposes? }\end{array}$ & 13.3 & 86.7 \\
\hline
\end{tabular}

Table 3

In Table 3, it can be seen that only 3 out of 15 participants (20\%) went to the kindergarten before school. This might be the reason why they did not pass the pre-test (Screening 1) at the early of the study. The importance of attending kindergarten or preschool should be taken into account by parents nowadays in order to make sure that their children get at least basic knowledge of learning English. This is highly supported by Chu (2014), who asserted that, "learning English at an early age has become significantly important for children Therefore, students should have the basic skill and knowledge in learning so that it would provide them a good foundation in learning.

From the questionnaire, the participants claimed that only 4 of them $(26.7 \%)$ who possessed their own smart phones while all of them stated that their family members have smart phones, which means that in their house has at least one smart phone to be used. For those who are not having their own smart phones $(73.3 \%)$, they reported that they usually use their family members' smart phones at home. Yet, there were only 2 of them $(13.3 \%)$ who declared that they use smart phones for learning purposes while the rest of them have not smart phones for learning. All of the participants (100\%) claimed that they love to learn English and also love to play online game. The data indicates that 13 over 15 participants $(86.7 \%)$ claimed that they play online game at home. In depth to that, there were only 2 of them (13.3\%) play online game for learning purposes while the rest of them stated that they play online game for selfsatisfaction.

Research Question Two: What are the students' perceptions toward learning English phonics using online game?

In Section 2 of the questionnaire, the perceptions of learning English phonics using online game were scrutinized and also have been put into simple percentages as displayed in the Table 4 below. 


\begin{tabular}{|r|l|l|l|}
\hline No. & Question & Yes (\%) & No (\%) \\
\hline 1. & Do you like to learn using technology (notebook)? & 100 & 0 \\
\hline 2. & $\begin{array}{l}\text { Have you ever been learning using online game before? } \\
\text { at school) }\end{array}$ & 0 & 100 \\
\hline 3. & $\begin{array}{l}\text { Do you like to learn English phonics using online } \\
\text { game? }\end{array}$ & 100 & 0 \\
\hline 4. & $\begin{array}{l}\text { Do you like to learn English using online game } \\
\text { compared to the common way of learning? }\end{array}$ & 100 & 0 \\
\hline 5. & Does the online game improve your English? & 100 & 0 \\
\hline 6. & Does the online game improve your phonics learning? & 100 & 0 \\
\hline 7. & $\begin{array}{l}\text { Does the online game improve your technology } \\
\text { awareness/skill? }\end{array}$ & 100 & 0 \\
\hline 8. & Does the online game improve your listening skill? & 93.3 & 6.7 \\
\hline 9. & Does the online game improve your reading skill? & 86.7 & 13.3 \\
\hline 10. & Does the online game improve your speaking skill? & 100 & 0 \\
\hline 11. & Does the online game improve your writing skill? & 0 & 100 \\
\hline 12. & $\begin{array}{l}\text { Does the online game promote you to work together } \\
\text { with your friends? }\end{array}$ & 100 & 0 \\
\hline 13. & Do you wish to have more lessons like this? & 100 & 0 \\
\hline 14. & $\begin{array}{l}\text { Do you feel more confident to learn English phonics } \\
\text { after the lessons? }\end{array}$ & 100 & 0 \\
\hline
\end{tabular}

\section{Table 4}

All of the participants (100\%) declared that they love to learn using technology (notebook), they like to learn English phonics using online game compared to learn it by using traditional way of learning, online game assists them to enhance comprehension in English and playing online game also helps them to escalate their knowledge in phonics learning as well as increasing their technology awareness and skills. Yet, all of them (100\%) reported that they never have their learning session using online game before. Regarding the development of language skills, the participants reported that learning using online game helps them in improving listening skills $(100 \%)$, reading skills $(86.7 \%)$, speaking skills $(100 \%)$ while none of them have improved on their writing skills. Moreover, these 15 participants (100\%) agreed that playing online game promotes teamwork among each other and wish to have this kind of lesson (learning using online game) afterwards.

\section{Interview}

From the interview, most of the respondents stated that they like the lesson because the instruction given was clear and easy to understand. They also informed that they can repeat the instruction for times if they did not listen to the instruction clearly. This proves that the online game utilized in this particular study which is 'Teach Your Monster to Read' was very appropriate and practical to be implemented in teaching English phonics to the students as they provide chances for the players to repeat instructions as many times as they wish. Hence, this helped the students to really understand the instruction to play the game very well. The examples of the details from the interview can be referred in the Table 5 below. 
*keyword: $\mathrm{R}=$ Respondent

\begin{tabular}{|c|c|}
\hline No. & Details \\
\hline 1. & $\begin{array}{l}\boldsymbol{R} 4: \text { jelas. Kalau tak jelas boleh ulang-ulang } \\
\text { It was clear. If not, the instructions can be repeated for times }\end{array}$ \\
\hline 2. & $\begin{array}{l}\text { R8: Boleh tekan lagi kalau nak dengar arahan banyak kali. } \\
\text { I can click on the button again if want to listen to the instructions many } \\
\text { Times }\end{array}$ \\
\hline
\end{tabular}

Table 5

In addition, teachers should ensure that the level of the game chosen is appropriate with the students' level of understanding. This is to make them to feel comfortable and pleased to play the game while learning as this would motivate them to learn further. From the data gathered, the students claimed that they love to play the game because it was easy so that they could win the game easily. The details from the interview can be referred in the Table 6 below.

\begin{tabular}{|r|l|}
\hline No. & Details \\
\hline 1. & $\begin{array}{l}\text { R1: } \text { senang nak main game tu } \\
\text { It was easy to play the game }\end{array}$ \\
\hline 2. & $\begin{array}{l}\text { R7: game dia senang } \\
\text { The game was easy to play }\end{array}$ \\
\hline
\end{tabular}

Table 6

In the study, the participants also reported that they love and enjoy playing the game because there will be rewards such as prizes and praises after they have completed the level. As rewards, they can choose their favourite attires such as hats and shoes to put on their characters (monsters). Some of the details from the interview can be referred in the Table 7 below.

\begin{tabular}{|r|l|}
\hline No. & Details \\
\hline 1. & $\begin{array}{r}\text { R10: } \text { best sebab lepas tu dapat hadiah } \\
\text { it was so fun as I can get prizes (awards in the game). }\end{array}$ \\
\hline 2. & $\begin{array}{r}\text { R11: seronok sebab lepas main boleh pilih hadiah } \\
\text { The game was fun because I can choose the prizes }\end{array}$ \\
\hline
\end{tabular}

\section{Table 7}

In order to keep the students to stay focus in learning, the presentation of the teaching and learning materials is highly significant to be highlighted by teachers. In this study, the game used contains characters which are not only familiar to the students but also interesting to them. This kind of situation may help the students to boost up their interest in learning as well as encourage them to keep learning. The data collected reveals that the students claimed that they like the characters in the game and the details of the data can be seen in the Table 8 below. 


\begin{tabular}{|r|l|}
\hline No. & Details \\
\hline 1. & $\begin{array}{l}\text { R2: saya suka kartun tu.dia comel. banyak warna } \\
\text { I love the cartoons (characters) in the game. Cute and colourful }\end{array}$ \\
\hline 2. & $\begin{array}{r}\text { R6: ' } m o n s t e r ' \text { dia comel } \\
\text { The monster was very cute }\end{array}$ \\
\hline
\end{tabular}

\section{Table 8}

There are factors that might help the students in developing their understanding in learning. However, there are also other factors that hinder their comprehension to be achieved well. In this particular study, the participants reported in the interview that they did not like this lesson (learning English phonics using online game) because sometimes the internet speed was very sluggish. Thus, it took quite some time for the website to load and they had to wait. As a result, no learning process can take place because the internet speed was one of the important factors that need to be taken into account in order to make the learning a success. The examples of the details from the interview have been transcribed and put into Table 9 below.

\begin{tabular}{|c|l|}
\hline No. & Details \\
\hline 1. & $\begin{array}{r}\text { R1 : Tapi kadang-kadang internet perlahan } \\
\text { But sometimes the internet speed was slow }\end{array}$ \\
\hline 2. & $\begin{array}{r}\text { R8 : } \text { kadang-kadang internet perlahan } \\
\text { Sometimes, the internet speed was slow }\end{array}$ \\
\hline
\end{tabular}

\section{Table 9}

\section{Discussion}

Colour is a very essential component in learning especially in memorizing contents. This notion is maintained by Mariam Adawiah and Muhammad Faiz (2013) who claimed that, "it (colour) functions as a powerful information channel to the human cognitive system and has been found to play a significant role in enhancing memory performance". In the game played in this study, all the materials and characters utilized are in coloured form. The students be keen on to see colourful images and more attracted to receive knowledge when the materials are in colours compared to the materials with no colours. This can be proved in a study carried out by Farley and Grant (1976) as cited in Mariam Adawiah and Muhammad Faiz (2013), who clarified that, "coloured multimedia presentations resulted in better attention and memory performance". Hence, the element of colours in the online game could help the students to retain their memory better and longer.

Since all students have different level of understanding, teachers may provide numbers and varieties of learning techniques and materials for the students to choose according to their own interest and capabilities. It helps the students to learn better as they can learn in their own way. This is highly supported by Bakar and Nosratirad (2013) as they asserted that, "the learning environment that gives freedom to learners to choose what type of learning they needed is important to encourage learners to study independently". Yet, teachers have to make sure that the teaching materials provided are suitable and contentful so that the learning is significant to them. According to Bakar and Nosratirad (2013), they declared that, "it can be concluded that, ESL and EFL language learning needs to be supported with meaningful learning tools, for example computer game, so that learning can be more realistic and 
meaningful". Regarding this study, teachers have to select appropriate reading materials such as phonics cards or simple story books in helping the students with their learning. Barrot (2015) discovered in her study that, "the implication of the findings for classroom teaching are considered more particularly in the selection of reading materials and the aspect of linguistic complexity that need to be adjusted to facilitate comprehension".

This game has developed on the main language skills which are listening, speaking and reading but the students showed no improvement in writing skill. Therefore, in future research, teachers may incorporate writing activity so that this skill could also be developed as well as other skills. As for beginning, teachers may use L1 to facilitate the students in writing because they might need more input in their first language. Kim and Yoon (2014) noticed that, "L1 use in writing L2 writing can play an encouraging role for both the ideational and compensatory purposes, suggesting that the strategic use of L1 can contribute to improvement in L2 composition". Besides, it is hoped that all parties including the authority (the government), teachers at school, parents at home as well as the society would work together in helping the learners today to develop their capabilities in learning English. Above all, teachers and parents play the most significant role in order to produce more successful learners. According to Kent and Facer (2004) as cited in Fu (2013) declared that, "school is an important environment in which students participate in a wide range of computer activities, while the home serves as a complementary site for regular engagement in a narrower set of computer activities".

\section{Conclusion}

To conclude, the implementation of online game in learning English phonics among the Year 1 students is very helpful in improving their phonics awareness and understanding. The lesson also develops their skills in handling technology tools; net book, 'mouse' and also playing an online game. Their confidence level also increases towards learning English phonics as they have demonstrated an improvement in their post-test (LINUS Screening 2). Supports from teachers and parents are very important in helping them to be at this stage. However, there are certain issues addressed that need to be taken into account such as the condition of the technology tools used or the internet speed during the lesson so that the learning can be carried out smoothly. Future research should consider the shortcomings encountered throughout this study. All in all, related stakeholders should play their own role in implementing online game in learning English phonics to be a success.

\section{References}

Ashraf, H., Motlagh, F.G., \& Salami, M. (2014). The impact of online game on learning English vocabulary by Iranian (low intermediate) EFL learners. Procedia-Social and Behavioral Sciences, 98, 286-291.

Bakar, N.A. \& Nosratirad, E. (2013). Sustaining vocabulary acquisition through computer game: A case study. Asian Social Science, 9 (5),235-242.

Barrot, J.S. (2015). Comparing the linguistic complexity in receptive and productive modes. GEMA Online Journal Of Language Studies, 15 (2), 65-81.

Berkling, K. \& Pflaumer, N. (2014). Phontasia- a Phonics trainer for German spelling in primary education. Aries, 14:15.

Birch, B.M. (2014). ( $3^{\text {rd }}$ Ed) English L2 reading: Getting to the bottom. New York \& London: Routledge.

Chang, M.M., \& Lin, M.C. (2013). Strategy-oriented web-based English instruction- A metaanalysis. Australasian Journal of Education Technology, 29 (2), 203-216. 
Chik, A. (2014). Digital gaming and language learning: Autonomy and Community. Language Learning \& Technology, 18 (2), 85-100.

Chu, Y.W. (2014). Teachers' beliefs in teaching English for kids at a kindergarten: A case study of students from the department of applied English. English Language Teaching, 7 (10), 100-112.

Crystal, D. (2013). A global language. In English in the World. Routledge; 163-208.

Dzulkifli, M.M. \& Mustafar, M.F. (2013). The influence of colour on memory performance: A review. The Malaysian Journal of Medical Sciences, 20 (2), 3-9.

Falloon, G. (2013). Young students using iPads:App design and content influences on their learning pathways. Computers \& Education, 68, 505-521.

Fu, J.S. (2013). ICT in education: A critical literature review and its implications. International Journal of Education \& Development using Information and Communication Technology, 9 (1), 112-125.

Godwin-Jones, R. (2014). Emerging Technologies Games in Language Learning: Opportunities and Challenges. Language Learning \& Technology, 18 (2), 9-19.

Kim, Y. \& Yoon, H. (2014). The use of L1 as a writing strategy in L2 writing tasks. GEMA Online Journal of Language Studies, 14 (3), 33-50.

McArthur, G., Eve, P.M., Jones, K., Banales, E., Kohnen, S., Anandakumar, T., Larsen, L., Marinus, E., Wang, H.C. \& Castles, A. (2012). Phonics training for English-speaking poor readers.

Ministry of Education. (2012). Preliminary Report: Malaysia Education Blueprint: 20132015.

Mohammad Ali Heidari-Shahreza, Moinzadeh, A. \& Barati, H. (2014). The effect of exposure frequency on incidental vocabulary acquisition. GEMA Online Journal of Language Studies, 14(1), 43-55.

Morse, J.M., \& Niehaus, L. (2016). Mixed method design: Principles and procedures. London \& New York: Routledge.

Phillips, J.A. (2013). Quantitative Research Methodology. Open University Malaysia. Selangor:Meteor Doc. Sdn Bhd.

Ryhan, E. (2014). The role and impact of English as a language and a medium of instruction in Saudi higher education institutions: students-instructors perspective. Study in English Language Teaching, 2 (2), 140-148.

Sayed Yusoff, S.H., Wee, H.T. \& Muhammad Zaffwan,I. (2014). Digital game-based learning for remedial Mathematics students: A new teaching and learning approach in Malaysia. International Journal of Multimedia and Ubiquitous Engineering, 9 (11), 325-338.

Singh, K.K.K. (2015). Qualitative Research Methodology. Open University Malaysia. Selangor: Meteor Doc. Sdn. Bhd.

Yang, F.Y., Chang, C.Y., Chien, W.R., Chien, Y.T. \& Tseng, Y.H. (2013). Tracking learners' visual attention during a multimedia presentation in a real classroom. Computers \& Education, 62, 208-220.

Yang, J.C. \& Quadir, B. (2018). Effects of Prior Knowledge on Learning Performance and Anxiety in an English Learning Online Role-Playing Game, Educational Technology \& Society, 21 (3), 174-185.

Yunus. M.M., Salehi, H. \& Amini, M. (2016). Impact of suing CALL on Iranian EFL learners' vocabulary knowledge. English Language Teaching, 9 (1),173-187.

Yunus, M., M. \& Sukri, S.I.A. (2017). The use of English in teaching Mathematics and Science: The PPSMI Polici vis-a-vis the DLP. Advances in Language and Literacy Studies. 8 (1). 